\title{
Studies on phospholipids of meat
}

\section{A method for the quantitative micro determination of individual plasmalogens by thin layer chromatography}

\author{
Takeo Nakanishi and Kyozo Suyama \\ (Laboratory of Chemistry and Technology of Animal Products, Faculty of Agriculture, \\ Tohoku University) \\ (Received for Publication on July 15, 1968)
}

Procedures for the quantitative determination of phospholipids have been successfully applied using thin layer chromatography (TLC). But no attempt to apply TLC to the determination of plasmalogen seems to have been made so far.

The methods used for the determination of plasmalogen in phospholipid fractions are the fuchsin-sulphurous acid method developed by FEULGEN ${ }^{31}$, its modifications $\mathrm{s}^{12,13)}$, the p-nitrophenylhydrazine method of PRIES ${ }^{11}$, the 2,4-dinitrophenylhydrazine method of KATz and KeENEY ${ }^{71}$, and the paper chromatographic method of $\mathrm{DAWSON}^{1,2)}$.

According to their original versions, the fuchsin-sulphurous acid method does not discriminate among phosphatidal ethanolamine, phosphatidal serine and phosphatidal choline, nor do the pnitrophenylhydrazine and 2,4-dinitrophenylhydrazine methods. The Dawson's method requires about 2 days for resolving and assaying plasmalogen sample.

The present report describes the application of TLC to the quantitative analysis of individual plasmalogens (phosphatidal ethanolamine, phosphatidal serine and phosphatidal choline). And with this method plasmalogens and usual di-acylated phospholipids, e.g., phosphatidal choline and phosphatidyl choline, can separately and simultaneously be determined.

\section{Materials and Methods}

1. Materials

a) Reagents

All solvents were reagent grade and distilled before use. By dissolving $\mathrm{HCl}$ gas, an approximately $3 \% \mathrm{HCl}$ solution in anhydrous methanol was prepared, and in which commercial pure DNP hydrazine [2,4-dinitrophenylhydrazine (Kanto Chem. Japan)] was dissolved to a concentration of $2 \%$. As a precautionary procedure, a fresh solution was prepared every 1 week. Hexadecanal was prepared according to the method of GRUNDMANN ${ }^{13}$.

For TLC, glass plates $(20 \times 20 \mathrm{~cm})$ were coated with Silica Gel H (E. Merck AG, Darmstadt, Germany) to a thickness of about $300 \mu$. After drying the plates were activated before use at $110^{\circ} \mathrm{C}$ for $2 \mathrm{hrs}$.

b) Samples of phospholipids

Samples of phospholipids were prepared from muscle tissue, liver and brain taken from Japanese Black Cattle.

Lipids were extracted first with chloroform-methanol $(2: 1 \mathrm{v} / \mathrm{v})$ following the method of Folch et $a l^{4}$. The extracts were washed twice with 0.2 volume of $0.9 \% \mathrm{NaCl}$ solution and 
dried at $40^{\circ} \mathrm{C}$ under the stream of nitrogen, and the residue was reextracted with chloroform. The surface of the extracted lipids was covered with nitrogen atmosphere whenever practicable.

Phospholipids were then separated by silicic acid (Mallinckrodt Chem., U.S.A. 100 mesh) column chromatography according to the procedure described in the previous paper ${ }^{8}$.

2. Outline of procedure

a) Chromatographic procequre

Sample Solutions of phospholipids were carefully applied each with a $50 \mu l$ syringe (Jintan Co., Japan, for gas chromatography) to a plate as a narrow streak of $0.5-1.0 \mathrm{~cm}$ wide, $1.5 \mathrm{~cm}$ from the bottom edge and $2 \mathrm{~cm}$ from the left edge. Quadruplicate aliquots of the same amount of phospholipids were placed in a micro Kjeldahl flask each for the determination of total phosphorus.

For the quantitative analysis of the usual di-acylated phospholipids, the sample solutions of which were applied to the plate in the same manner, $1.5 \mathrm{~cm}$ from the bottom edge and $2-3 \mathrm{~cm}$ from the right edge (see Fig. 1). For the quantitative analysis of individual phospholipids, the plates were subjected to ascending chromatography in the chloroform-methanol-acetic acidwater (25:15:4:2, by volume) following the procedure described by PARKER et al. ${ }^{10}$ ). Various solvent systems can be used.

b) Formation of DNP hydrazones.

After the solvents were removed perfectly under the stream of nitrogen at room temperature, the plates on which the bands of separated phospholipids (about $2 \mathrm{~cm}$ wide, see Fig. 1) existed were sprayed with DNP hydrazine solution in $\mathrm{HCl}$-methanol till the bands got wet and became transparent, then leaned in the air at room temperature for $20 \mathrm{~min}$. till methanol was mostly removed, and then placed in a vacuum desiccator for $2-3 \mathrm{hrs}$ or in a drying oven at $100^{\circ} \mathrm{C}$ for $10 \mathrm{~min}$.

c) Separation and detection of DNP hydrazones

The resulting products were developed in a second dimension with petroleum benzine (b.p. $\left.60-70^{\circ} \mathrm{C}\right)$-ethyl ether-acetic acid $(80: 20: 3$, by volume). In this solvent system DNP hydrazones moved readily, while excess of DNP hydrazine remained at the origin upon the TLC plate. The Rf values of yellow spots of DNP hydrazones were about 0.7 .

The DNP hydrazones formed from phosphatidal ethanolamine, phosphatidal serine and phosphatidal choline could be detected by the Rf values of the spots of ethanolamine, serine and choline phospholipids developed on the same plate, respectively (see Fig. 1). For the detection of ethanolamine and serine phospolipids and choline phospholipids, ninhydrine spray and Dragendorff reagent spray were used respectively.

d) Separation and detection of total plasmalogen

Total plasmalogen in total phospholipid can be separated and detected in the following manner. Sample solutions of total phospholipid in chloroform were carefully applied each with a $50 \mu l$ syringe to a plate as a round spot of apout $1 \mathrm{~cm}$ in diameter. After removing the solvent from the spot under the stream of nitrogen, the spot was sprayed with DNP hydrazine solution in HCI-methanol. The DNP hydrazones formed from aldehydes of total plasmalogen were developed with petroleum benzine (b.p. $60-70^{\circ} \mathrm{C}$ ) -ethyl ether-acetic acid $(80: 20: 3$ ) after drying the plate in the air at room temperature for 20 min. (see Fig. 2).

e) Quantification of DNP hydrazones

After the solvent had been removed from the plate, each outlined spot of each DNP hydrazone and mixed hydrazones from each plasmalogen and total plasmalogen, respectively, was 


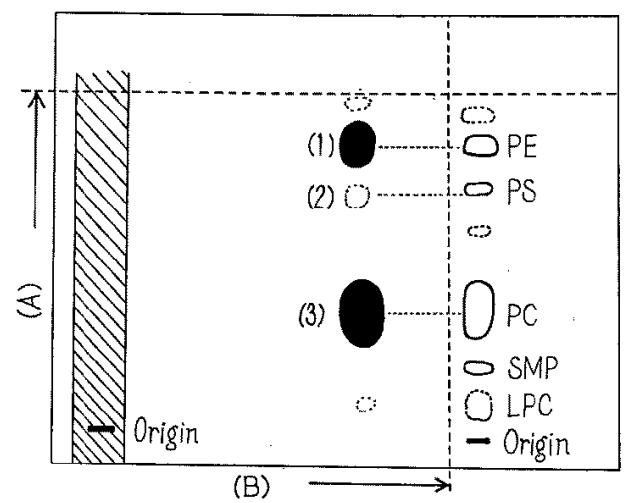

IIV:Area sprayed with 24-dinitrophenyl hydrazine solution

Fig. 1. Tracing of a thin-layer chromatogram of phospholipids from cattle skeletal muscle extracts. The chromatogram was developed in chloroform-methanol-acetic acid-water (25:15:4:2, by vol.) (Solvent $A$ ), and then petroleum benzin (b.p. $60-70^{\circ} \mathrm{C}$ ) -ethyl ether-acetic acid $(80: 20: 3$, by vol.) (Solvent B). Experimental details are given in the text. PE: phosphatidyl ethanolamine+phosphatidal ethanolamine, PS: phosphatidyl serine + phosphatidal serine, PC: phosphatidyl choline+phosphatidal choline, SMP: sphingomyelin, LPC: Lysophosphatidylcholine. Detection method: $40 \%$ sulphuric acid spray. Each yellow DNP hydrazone spot was identified as: (1) phosphatidal ethanolamine aldehyde, (2) phosphatidal serine aldehyde, (3) phosphatidal choline aldehyde.

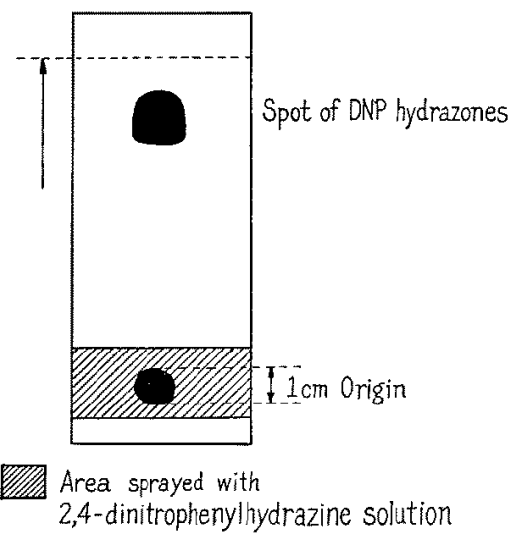

Fig. 2. Tracing of a thin layer chromatogram of 2,4-dinitrophenylhydrazones formed from aldehydes of total plasmalogen. The chromatogram was developed in petroleum benzine (b.p. $60-70^{\circ} \mathrm{C}$ )-ethyl ether-acetic acid $(80: 20: 3$ by vol.). Experimental details are given in the text. 


\section{NAKANISHI - SUYAMA}

scraped directly into a $10 \mathrm{~m} l$ stoppered centrifuge tube, to which $10 \mathrm{~m} l$ of chloroform was added, and then centrifuged after vigorous shaking. The chloroform solution of each DNP hydrazone or mixed hydrazones was determined at $358 \mathrm{~m} \mu$ in a $1 \mathrm{~cm}$ cell against a blank prepared in the absence of DNP hydrazones, where according to JonEs et al. ${ }^{\text {) }}$ the length of the carbon chain of DNP hydrazones does not cause any measurably changes in the figures for the absorption maximum and the molar extinction coefficient (except formaldehyde and $\alpha, \beta$ unsaturated aldehyde DNP hydrazones), and these facts have been reconfirmed in the present work.

Aldehydes of plasmalogens of biological samples are usually $\mathrm{C}_{12}-\mathrm{C}_{18}{ }^{5,9)}$ aldehydes, and among them hexadecanal and octadecanal are predominant aldehydes. From this fact, an optional aldehyde DNP hydrazone formed from one of these $\mathrm{C}_{12}-\mathrm{C}_{18}$ aldehydes, e.g., hexadecanal DNP hydrazone, can be used as a standard material in the determination of aldehydes of plasmalogens by spectrophotometric procedure. In this experiment hexadecanal DNP hydrazone was used as the standard material, the absorption maximum and the molar extinction coefficient of this material was $358 \mathrm{~m} \mu$ and 21600 , respectively (Fig. 3).
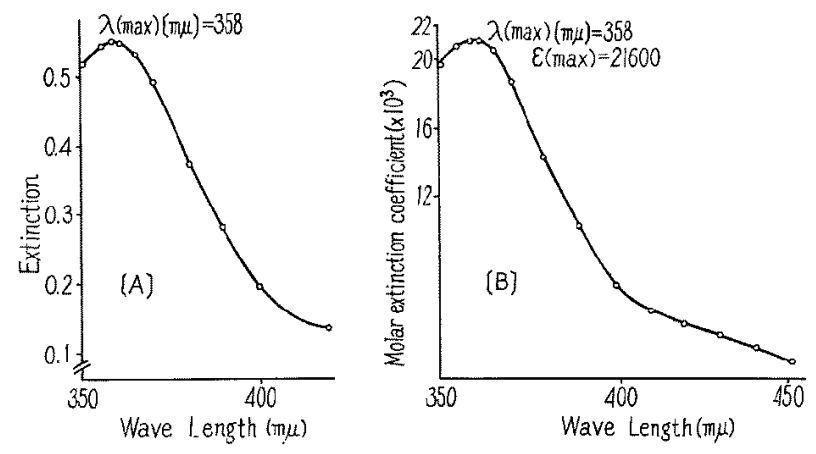

Fig. 3. Absorption spectra of 2,4-dinitrophenyl hydrazones formed from aldehydes of total plasmalogen of cattle skeletal muscle $[\mathrm{A}]$ and $\mathrm{n}-$ hexadecanal 2, 4-dinitrophenyl hydrazone [B]

\section{Results}

1. Formation of DNP hydrazones

a) Effect of reaction time

The effect of reaction time on the formation of DNP hydrazones on TLC plates is shown in Fig. 4. A sample solution of phospholipids isolated from skeletal muscle of cattle was spotted as a circle of about $1 \mathrm{~cm}$ in diameter. After removing the solvent from the spot under the stream of nitrogen, the spot was sprayed with DNP hydrazine solution. And then the plate was allowed to stand in a chamber saturated with methanol vapor for 2-120 min. at room temperature. At various reaction time intervals, DNP hydrazones of plasmalogens formed were developed with petroleum benzine-ethyl ether-acetic acid (80:20:3) and determined by the spectrophotometric procedure.

Under the given condition the reaction seems to have been completed in less than 10 min., and the theoretical amounts of DNP hydrazones seem to have been formed within the time required for the removal of methanol in atmospheric condition at room temperature $(20 \mathrm{~min}$.) 
Quantitative determination of plasmalogens

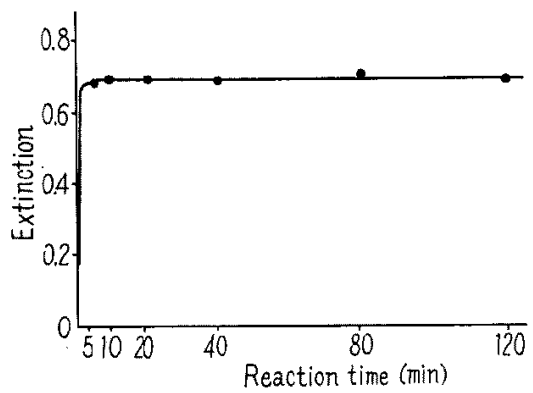

Fig. 4. Effect of reaction time of aldehydes of total plas. malogen with 2,4-dinitrophenylhydrazine on the formation of DNP hydrazones on thin layer plate. $0.352 \mathrm{~mol}$ of plasmalogens isolated from skeletal muscle was used. The extinction was determined at $358 \mathrm{~m} \mu$ against a chloroform blank. Experimental details are given in the text.

b) Relation between the quantity of total plasmalogen and the finding for extinction at $358 \mathrm{~m} \mu$.

A known amount of phospholipids (a known amount of total plasmalogen) isolated from skeletal muscle of cattle was applied to the TLC plate as a round spot of about $1 \mathrm{~cm}$ in diameter. DNP hydrazones of plasmalogens were formed, developed and determined by the same methods as are described above.

In Fig. 5 the relation between the quantity of total plasmalogen and the finding for extinction at $358 \mathrm{~m} \mu$ is shown. From the results, BEER's law was found to hold within the range below $0.44 \mathrm{~mol}$, and therefore Fig. 5 was used as the estimation curve of plasmalogen.

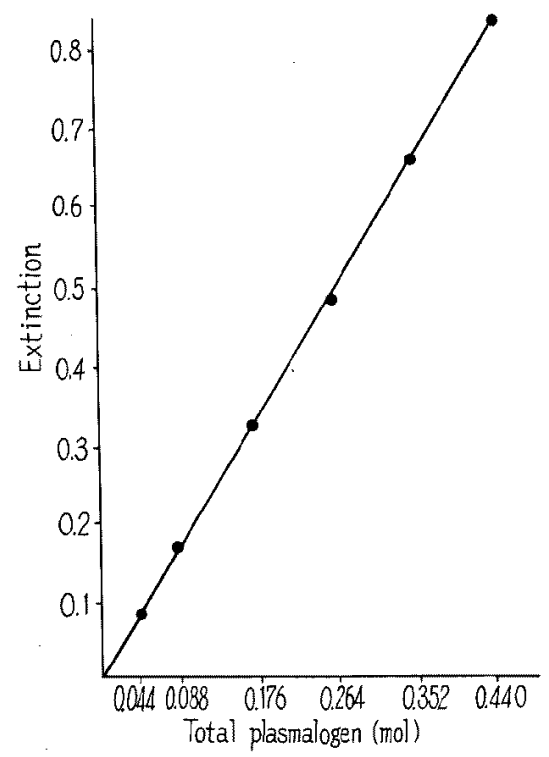

Fig. 5. Relation between the quantity of total plasmalogen of cattle skeletal muscle and the finding for extinction at $358 \mathrm{~m} \mu$. Experimental details are given in the text. 
c) Absorption spectra of DNP hydrazones

The absorption spectra in chloroform of DNP hydrazones formed from total plasmalogen isolated from cattle skeletal muscle and n-hexadecanal are shown in Fig. 3. Since it was found that both absorption spectra were quite the same, $n$-hexadecanal DNP hydrazone can be used as the standard material.

d) Content of total plasmalogen and distribution of individual plasmalogens in cattle tissues

The content of total plasmalogen in total phospholipid and the distribution of individual plasmalogens in total plasmalogen in liver, skeletal muscle and brain of cattle are given in Table 1, where the percentages of total plasmalogen and each plasmalogen were calculated as follows.

$$
\begin{aligned}
& \text { Total plasmalogen }=\frac{\text { Total plasmalogen aldehyde }(\mathrm{mol})}{\text { Total } P(\mathrm{~mol})} \times 100(\%) \\
& \text { Each plasmalogen }=\frac{\text { Each plasmalogen aldehyde }(\mathrm{mol})}{\text { Total plasmalogen aldehyde }(\mathrm{mol})} \times 100(\%)
\end{aligned}
$$

The estimations were performed in duplicate runs showing close agreement.

Table 1. Distribution of individual plasmalogens in tissues of cattle

\begin{tabular}{l|ccc}
\hline \hline & Skeletal muscle & Liver & Brain \\
\hline $\begin{array}{c}\text { Total Plasmalogen (\%) } \\
\text { (mol aldehyde/mol P) }\end{array}$ & 16.1 & 2.6 & 12.9 \\
$\begin{array}{c}\text { Individual plasmalogens (\%) } \\
\text { Phosphatidal ethanolamine }\end{array}$ & 31.9 & 86.3 & 90.8 \\
Phosphatidal choline & 64.8 & 10.7 & 6.7 \\
Phosphatidal serine & trace & 2.0 & 2.5 \\
\hline
\end{tabular}

The present results (Table 1) indicated that phosphatidal ethanolamine was the predominant plasmalogen in brain, whereas in skeletal muscle phosphatidal choline was predominant. A fairly less amount of total plasmalogen was detected in liver as compared with those in skeletal muscle and brain.

\section{Conclusion}

The present method of determining the plasmalogens in a tissue has certain advantages over the conventional methods. The method requires only small amounts of tissues and is rapidly carried through. Furher, individual di-acylated phospholipids and plasmalogens can be determined simultaneously by the estimations of phosphorus of the spots upon the TLC plate (Fig. 1).

We have noted that in general, when the samples of pure, freshly isolated phospholipids were assayed for aldehydogenic material, the DNP hydrazones consisted almost entirely of long-chain $\left(\geqq \mathrm{C}_{12}\right)$ aldehyde ${ }^{5,9)}$ DNP hydrazones. But when the samples of crude phospholipids or older partially oxidized lipids were assayed, some DNP hydrazones presumably formed from the aldehydes contaminated the crude lipids or produced by the partial oxidation of lipids, were usually found to migrate more slowly than long-chain aldehyde DNP hydrazones.

Finally, this method may be applied to the determination of the sum of free aldehydes and bound aldehydes to plasmalogen and their respective amounts in lipid fraction by means of the 


\section{Quantitative determination of plasmalogens}

nonpolar solvent system for the development of one dimentional TLC. This idea is supported by the fact that when the samples of total lipid were developed with petroleum benzine (b.p. $\left.60-70^{\circ} \mathrm{C}\right)$-ethyl ether-acetic acid $(80: 20: 3)$, the Rf values on TLC of free fatty aldehydes were $0.7-0.8$ and those of plasmalogens were zero.

\section{Summary}

1. A method is presented for the rapid quantitative micro determination of the individual plasmalogens of biological sample.

2. The 2,4-dinitrophenylhydrazones of individual plasmalogen aldehydes were formed on the thin layer chromatoplate after phospholipids were separated by the first dimentional thin layer chromatography. The hydrazones formed were then isolated by the second dimentional thin layer chromatography, and then the hydrazones were determined by a spectrophotometric procedure.

3. By this method, the distribution of phosphatidal ethanolamine, phosphatidal serine and phosphatidal choline has been measured in three tissues of cattle.

\section{References}

1) Dawson, R.M.C. (1960) Biochem. J., 75: 45-53.

2) Dawson, R.M.C., N. Hemington and J.B. Davenport (1962) ibid., 84: 497-501.

3) Feulgen, R., W. Bogth and G. Andresen (1951) Z. Physiol. Chem., 287: 90-108.

4) Folch, J., M. Lees and G.H. Sloane-Stanley (1957) J. Biol. Chem. 226: 497-509.

5) GrAY, G.M. (1960) Biochem. J., 77: 82-91.

6) Jones, L.A., J.C. Holmes and R.B. Seligman (1956) Anal. Chem. 28: 191-198.

7) KatZ, I. and M. KEENEY (1966) J. Lipid Res., 7: 170-173.

8) Nakanishi, T and K. Suyama (1966) Jap. J. Zootech. Sci., 37: 375-381.

9) Nakanishi, T. and K. SuYama (1967) ibid., 38:262-268.

10) Parker, F. and E.H. Ahrens (1965) J. Lipid Res., 6: 455-460.

11) Pries, C. and J.F. Bottcher (1965) Biochem. Biophys. Acta., 98: 329-334.

12) Rapport, M.M. and N. Alonzo (1955) J. Biol. Chem., 217: 199-204.

13) Warner, H.R. and W.E.M. LANDS (1963) J. Lipid Res., 4: 216-220.

14) Zikkenkagaku koza (1958) Maruzen 19: 256-258. 


\title{
食肉の燐脂質に関する研究
}

VII. 薄層クロマトグラフィーによる個々のプラズマローゲンの微量定量法

\author{
中西武雄・須山享 三 \\ (東北大学覀学部)
}

本法はブラス゚マローダンに結合したアルデヒドを定 量することにより，総プラズマローゲンおよび個々のプ ラズマローグン定微是かつ迅速に定量する方法である。

1. 薄層クロマトプレート上で，一次脿䦌により分踓

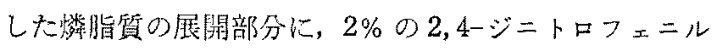
ヒドラジンの3\%塩酸ーメタノール溶液安過剩に貲麗し,
プラズマローゲンのフルデヒドの DNP ヒドラゾンを生 成させ，乾燥後 2 次展開により生成したヒドラソンを分 離定量し，これから総プラズマローゲンおよび個々のプ ラズマローゲンを定量した。

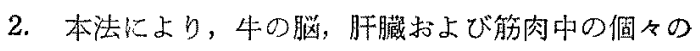
プジズマローゲンの定量を行なった。 